Mr. Nevzet Veladžić

\title{
DRUŠTVENO-POLITIČKA I KULTURNA DIMENZIJA DJELOVANJA MEHMEDA DŽEMALUDINA ČAUŠEVIĆA
}

Sažetak

U radu se nastoji rasvijetliti povijesna uloga Džemaludina Čauševića ne samo u religijskom već, prije svega, $s$ aspekta društveno-političkog i kulturnog značenja. Posebna pažnja posvećena je društveno-političkom ambijentu jer koliko god je Čaušević bio nadahnut reformatorskim mladoturskim idejama toliko ga je definiralo vrijeme, društveno-političke prilike u kojima je živio. Gotovo da ne postoji turbulentnije razdoblje u ukupnoj bosanskohercegovačkoj povijesti do onog zadnjih decenija 19. do prve polovine 20. stoljeća. To je razdoblje u kojem se «svaki dan» bilježila povijest. U tom kontekstu, kroz prizmu povijesnih događanja rad govori o utjecaju na ukupne društveno političke i kulturne prilike koji je Čaušević ostavio.

Nedvojbeno je da je taj utjecaj bio snažan, o čemu govore brojne činjenice koje su u radu prezentirane. Jedna od činjenica jeste svakako mehanizam odašiljanja poruka prema stanovništvu kada su mediji bili u začetku svog razvoja. Broj konzumenata koji su primali poruke tim putem bio je reduciran. Iako je aktivno koristio tadašnje medije, najdjelotvornija tadašnja metoda komunikacije sa stanovništvom je «džamija» putem koje je njegova poruka u kratkom vremenu (sedam dana) stizala do većine stanovnika BiH.

$\mathrm{Na}$ kulturnom planu, snagom svog autoriteta, čini da se otklone stereotipi kod Bošnjaka muslimana o zapadnoj kulturi i svemu onome što dolazi s njom kao neprijateljskoj $i$ «vlaškoj» kulturi. Čak $i$ dio uleme je bio opterećen takvim stereotipima što je dodatno otežavalo njegov rad. Činjenice koje su iznesene u radu svrstavaju ga u grupu velikana bosanskohercegovačke novije povijesti.

O životu i djelu Džemaludina Čauševića

Ovaj bosanski velikan rođen je 28. decembra 1870. godine u sjeverozapadnom dijelu Bosne, preciznije u selu Arapuša, nedaleko od 
Bosanske Krupe. Samo tri dana nakon njegovog rođenja umire mu majka tako da od najranijeg djetinjstva odrasta kao siroče. Njegov otac Ali-efendija (u Bosanskoj Krajini poznatiji kao Ali-hodža Čaušević) preuzima roditeljsku brigu $u$ odgoju i početnom obrazovanju Džemaludina Čauševića te njegovim obrazovnim pripremama za upis u medresu. Mehmed Džemaludin Čaušević upisuje Bihaćku medresu 1880. godine i uči pred hadži Ahmedom Sabit-efendijom Ribićem. Nakon završene medrese odlazi na dalje školovanje u Istanbul. Studirao je pravo, turski jezik, književnost, teologiju, filozofiju, misticizam i povijest pred profesorima H. Halisefendijom i Nevšeherlijom. Stekao je idžazet (veniam legendi) pred profesorom H. Hasanom Husni-efendijom. Godine 1898/1903. upisuje se na Mektebi-nuwwab, a potom prelazi na Mektebi-hukuk (pravni fakultet) koji završava odličnim uspjehom. ${ }^{1}$

Odmah po odlasku na školovanje u Istanbul Mehmed Džemaludin Čaušević je bio zaokupljen idejama mladoturskog pokreta, a nedugo poslije toga pristupa tom poznatom reformatorskom pokretu te drži predavanja u reformatorskim krugovima tadašnje Osmanske imperije. ${ }^{2}$ Sklopio je prijateljske odnose sa Ahmedom Dževdet-pašom, Hakki-pašom te njihovim intelektualnim krugom. Šrio je njihove reformatorske ideje i uživao njihovu moralnu podršku i zaštitu. Također, Mehmed Džemaludin Čaušević je bio i povremeni novinski suradnik za istanbulske reformatorske novine. Tokom svog studiranja u Istanbulu u više navrata boravio je u drugim gradovima Kairu, Jeruzalemu, Jemenu, Damasku i Ankari. Poseban interes izrazio je prema egipatskom reformatoru Muhammedu Abduhu, kojeg je posjetio 1901. godine i koji će svojim reformatorskim idejama na njega izvršiti snažan utjecaj.

Nakon dugog odsustva iz Bosne, Mehmed Džemaludin Čaušević 1901. godine dolazi u Sarajevo, gdje ostaje nekoliko mjeseci. Tokom svog boravka u Sarajevu iskoristio je ponuđenu priliku da održi nekoliko predavanja u Begovoj džamiji, što je tada bila izuzetna čast. Njegova predavanja i percepcija islama koju je iznosio u svojim izlaganjima odudarale su od tradicionalnog pristupa

\footnotetext{
${ }^{1}$ U vrijeme kada je pohađao Mektebi-hukuk, Čaušević je za učitelja imao tadašnji autoritet Ismaila Hakki-efendiju Manastirliju.

${ }^{2}$ Predavanja je držao širom Osmanske imperije - u Makedoniji, Anadoliji, Istanbulu i drugim većim centrima
} 
koji je egzistirao u tom razdoblju. Već tada, svojim moralnim dignitetom, obrazovanjem i reformatorskim idejama na sebe skreće pažnju u intelektulanim krugovima.

Ponovni dolazak iz Istanbula je 1903. godine kada odlučuje da ostane u Bosni te se zapošljava kao učitelj arapskog jezika na Velikoj gimnaziji u Sarajevu. ${ }^{3}$

U februaru 1905. godine imenovan je za člana najvišeg upravnog tijela Islamske zajednice u Bosni i Hercegovini, Ulemamedžlisa. Nakon što je proučio društvenopolitičke, vjerske, kulturne i ekonomske prilike u Bosni i Hercegovini, pod utjecajem mladoturskog reformskog pokreta te egipatskog reformatora Muhammmeda Abduhua, pokušava dati svoj doprinos u razrješavanju već nagomilanih društvenih problema opterećenih snažnim tradicionalnim okovima, s jedne, i naleta «novog» (zapadnog), s druge strane. Godine 1905. radio je sa Agof-ef. Zeronianom na projektu novog pisma «arebice». ${ }^{4}$ Značaj ovog pisma Mehmed Džemaludin Čaušević vidi u prevladavanju suprotnosti koje dolaze s AustroUgarskom i njenim uvođenjem latiničnog pisma, koji bojkotiraju Bošnjaci muslimani, i pokušaju da se oni putem reformiranog obrazovnog sistema uključe u društvene tokove ovog dinamičnog razdoblja. Islamska dionička štamparija je prihvatila ovaj projekt te je počela štampati knjige i časopise na ovom pismu (arebici).

Godine 1906. uređuje list Behar, a 1907. pokreće i izdaje kalendar Mekteb. Jedan je od pokretača lista Tarik, u kojem širi prosvjetne ideje na bosanskome jeziku. Mehmed Džemaludin Čaušević je 1910. godine imenovan na mjesto profesora u Šerijatskoj školi, gdje ostaje do 1912. godine kada podnosi ostavku. Početkom

\footnotetext{
${ }^{3}$ Kasnije se zvala Prva muška gimnazija.

${ }^{4}$ Arebica je arapsko pismo prilagođeno za pisanje tekstova na bosanskom jeziku. U literaturi ovo pismo je poznato i pod nazivima hrvatica i matuhica Od nastanka arebice (XVII vijek) traju pokušaji da se grafijski prilagodi glasovnim osobinama bosanskog jezika. Upotrebu arebice tokom njenog egzistiranja od XVII vijeka nije pratila nikakva ortografska norma, već se uglavnom koristila turska verzija arapskog pisma. Tek krajem XIX i početkom XX vijeka pojavljuju se radikalniji poduhvati u pravopisnim reformama arebice. Prvu značajniju reformu arebice izvršio je Omer Humo, ali isto tako važno je istaći reformske pokušaje Ibrahima Berbića, Ibrahima Seljupca i Junuza Remzije Stovre. Međutim, najznačajniji rad na reformi arebice je, definitivno, uradio Džemaludin Čaušević.
} 
1913. godine Hodžinska kurija bira Čauševića za reisul-ulemu Bosne i Hercegovine.

Čaušević se 1914. godine oženio Pandža Hatidžom (sestrom hafiza Muhameda Pandže, Čauševićevog velikog prijatelja i suradnika na prijevodu Kur'ana).

U periodu Prvog svjetskog rata (1914 -1918), u vrlo teškim uvjetima Čaušević je radio na reformi učiteljske škole (Darulmuallimin) i Gazi Husrev-begove medrese. Također, 1918. godine otvara Okružnu medresu, a 1919. godine Šerijatsku gimnaziju u Sarajevu. Iste godine daje intervju uglednom pariškom novinaru Charlesu Rivetu (za list «Temps»). Tu javno iznosi da bosanski muslimani proslavljaju rođendan versajske Jugoslavije u krvi, ognju i plamenu. Izjavio je da je od nastanka Jugoslavije do proljeća 1919. godine ubijeno na hiljade ljudi muslimana, spaljeno 76 žena i razoreno i opljačkano 270 sela. U istom intervjuu traži zaštitu od Francuske.

Drugu prosvjetnu anketu, koja je imala za cilj reformu Gazi Husrev-begove medrese te medresa i drugih islamskih prosvjetnih zavoda u Bosni i Hercegovini, Čaušević pokreće 1920-1921. godine.

Krajem 1929. godine reis Čaušević se oštro usprotivio prijedlogu Milana Srškića, ministra pravde Kraljevine Jugoslavije, koji na osnovu donesenog Zakona o Islamskoj vjerskoj zajednici Kraljevine Jugoslavije (od 31. januara 1930. godine) želi ukinuti autonomiju Islamske zajednice. Po tom zakonu ministar pravde je najviša upravna vlast koja vrši nadzor nad radom IVZ-a (Islamske vjerske zajednice) kao i nadzor nad vakufsko-mearifskim poslovima. ${ }^{5}$

Neposredno poslije toga, 11.aprila 1930. godine, reis Čaušević upućuje pismo ministru pravde Milanu Srškiću tražeći da ga penzionira. On u svom pismu navodi razloge ostavke te ultimativno traži «Ukaz o razrješenju» pa makar i ne dobio penziju, jer nije htio «snositi odgovornost koja nije spojena sa pravom».

5 Milan Srškić je «nudio» reisu Čauševiću da ga vlast imenuje reisul-ulemom Jugoslavije a da za uzvrat prihvati Zakon o Islamskoj vjerskoj zajednici, kojim se praktički ukida njena autonomija. U odgovoru Milanu Srškiću Mehmed Džemaludin Čaušević kaže: "Doznao sam da se zakon o islamskoj vjerskoj zajednici donosi onako kako ja nijesam zagovarao i da se ne uzimaju u obzir moji zahtjevi. Ja molim jasan odgovor prije donošenja toga zakona jer sam pripravan da zamolim Njegovo Veličanstvo da ustegne sankciju ili da me dužnosti vjerskog poglavara razriješi." 
U periodu 1933-1937. aktivno radi na bosanskom prijevodu Kur'ana sa hafizom Muhamedom Pandžom. Prijevod izlazi iz štampe 1937. pod nazivom Kur'an časni.

Mehmed Džemaludin Čaušević je umro nakon kraće bolesti 28. marta 1938. godine u Državnoj bolnici u Sarajevu.

\section{Uvod}

Mehmed Džemaludin Čaušević svojim životnim djelom označio je jedno od najdinamičnijih i najturbulentnijih razdoblja bosanskohercegovačke povijesti (raspad Osmanskog carstva, dolazak Austro-Ugarske, Prvi svjetski rat i stvaranje Kraljevine Jugoslavije) i predstavlja značajnu figuru, ne samo islamskog mišljenja u Bosni i Hercegovini na prijelazu XIX u XX stoljeće već ukupne njene povijesti, kulture i politike. Nakon školovanja na tadašnjim prestižnim učilištima Istanbula, vraća se u «neizvjesnu» Bosnu sa najvišom obrazovnom diplomom i uključuje u vjerski, društveni, kulturni a kasnije i politički život Bošnjaka.

Svoj društveni, kulturni i vjerski utjecaj počinje ostvarivati početkom XX stoljeća, po povratku sa svog sedamnaestogodišnjeg školovanja u Istanbulu. Taj utjecaj postaje mnogo snažniji od 1913. do 1930. godine kada je nosio titulu, bez sumnje, najistaknutijeg vjerskog lidera, odnosno kada se nalazi na poziciji reisa. Mnogima nije odgovarao njegov izbor za reisul-ulemu, što se vidi iz pokušaja Zemaljske vlade da, nakon što ga je Hodžinska kurija 1913. godine izabrala, poništi njegov izbor. Međutim, iste godine Hodžinska kurija je ponovo izabrala Mehmeda Džemaludina Čauševića na funkciju reisul-uleme. Taj izbor potvrđuju svojim aktima o postavljenju i osmanski sultan i austrougarski car; jedini je reis u povijesti kojeg su spletom historijskih i društveno-političkih prilika imenovale dvije krune.

Izrastao je u krupnu historijsku ličnost koja je u sebi objedinjava mnoge vrijednosti - duhovne, političke, prosvjetiteljske - i koja postaje neprikosnovena, možda jedina, karizmatska ličnost Bošnjaka muslimana tog vremena. On stečeno znanje i usvojene reforme u svim oblastima života želi da usadi u Bosnu. Naravno, otpori su očekivani i raznovrsni, međutim, on ustrajno, mudro zna plasirati i u djelo sprovesti svoje ideje. Konzervativizam i naslijeđeni 
primitivizam, istina, usporavaju, ali ne dovode $u$ pitanje njegove namjere.

U bosanskohercegovačkoj sociološko-politološkoj pa i u historiografskoj literaturi postoji teorijsko-znanstvena praznina $u$ pogledu istraživanja i monografskog elaboriranja, pored teološke, i društveno-političke uloge Džemaludina Čauševića i njegove borbe za ostvarivanje bošnjačkih prava. Razlozi su, između ostalih, što je Džemaludin Čaušević izučavan isključivo sa religijskog aspekta, a ne s aspekta njegovog sveobuhvatnog učenja i djelovanja.

Naravno, ovaj teorijsko-znanstveni vakuum ne podrazumijeva ignoriranje činjenice da postoje u našoj znanstvenoj literaturi fragmentarni uvidi i studijske interpretacije pojedinih aspekata historije i teologije o društvenoj i političkoj ulozi Džemaludina Čauševića u ostvarivanju bošnjačkih kulturnih, vjerskih, političkih i ostalih prava koje posjeduju druge religijske i nacionalne skupine. Naprotiv, postoje značajna djela, kao nedavno izašlo djelo «Reis Džemaludin Čaušević, reformator i prosvjetitelj» autora Enesa Karića i Muje Demirovića, kao i radovi Mahmuda Traljića i Mustafe Imamovića, koji su u pojedinim oblastima dali doprinos $\mathrm{u}$ rasvjetljavanju lika i djela Džemaludina Čauševića.

Polazeći od te činjenice, stoji znanstvena potreba da se na sintetički način, u monografskom smislu istraže i protumače društveno-politička djelovanja Džemaludina Čauševića koji, zbog nesumnjivo ogromnog društvenog doprinosa, pripada krugu povijesnih bosanskohercegovačkih velikana.

\section{Reis Džemaludin Čaušević - svjedokjednog vremena}

Početkom XX stoljeća društveno-političke prilike u Bosni i Hercegovini zahtijevale su širu društvenu akciju bošnjačkih intelektualnih krugova kako bi se ostvario adekvatan položaj Bošnjaka u novim državnim formama. Postoji veliki broj znanstvenih radova koji su tematizirali ovaj period nudeći nam određena znanja o društvenom, političkom, ekonomskom, kulturnom pa i religijskom životu. Međutim, svi istraživački radovi upućuju nas na izuzetno težak položaj Bošnjaka u već započetom procesu realizacije ideje o jugoslavenskoj državi. U tom se razdoblju Čaušević nameće svojim reformatorskim i prosvjetiteljskim idejama kao faktor zaštite prava Bošnjaka i njihova nacionalnog i vjerskog individualiteta unutar 
novostvorenih državnih formi. U ovom radu ćemo pokušati rekonstruirati povijesnu ulogu Džemaludina Čauševića i znanstveno predstaviti njegov ogromni doprinos u oblikovanju ideja i kulturnopolitičkih ciljeva koji će pomoći opstanku Bošnjaka u periodu velikosrpskih i velikohrvatskih teritorijalnih aspiracija, ali bez namjere da to bude puko opisivanje.

Snažan bošnjački konzervativizam koji je bio prepreka razvoju građanske svijesti, s jedne, i ugroženost bošnjačkih osnovnih prava $i$ sloboda, s druge strane, zahtijevale su društveno-političku borbu u oba pravca. Ne zanemarujući i ne umanjujući značaj ostalih ličnosti bošnjačke povijesti, Džemaludin Čaušević spada u red onih koji su svojim idejama i radom u velikoj mjeri odredili sudbinu daljeg razvoja Bosne i Hercegovine i Bošnjaka u njoj, te egzistiranje islama na području bivše Jugoslavije. Otuda se javlja nužnost znanstvenog rasvjetljavanja, osim teološke, i društveno-političke uloge Džemaludina Čauševića.

U ovom radu ćemo se pokušati fokusirati na nekoliko dimenzija njegova djelovanja: društvenoj, političkoj, religijskoj i kulturnoj dimenziji.

Svakako, na samom početku smatramo izuzetno važnim naglasiti Čauševićevo shvaćanje fenomena bošnjaštva kao nacionalne identifikacije kroz povijesnu prizmu. Bosna i Hercegovina je povijesno postojala kao teritorijalni, običajno-kulturni, političkopravni i državni identitet. Međutim, taj identitet je tokom cijelog XX stoljeća bio, i jeste još uvijek, glavni «predmet» osporavanja, s jedne, $\mathrm{i}$ afirmiranja, s druge strane. Bošnjački nacionalni identitet, baš kao i politički i društveni i kulturni, nije gotova stvar, nije već nešto «dato», postignuto i zaokruženo. On je proces svijesti koji treba razumjeti i neprestano ga oblikovati i usmjeravati.

Predmet objekcije i verifikacije bošnjačkog nacionaliteta nužno iziskuje realni okvir historijskog i geopolitičkog prostora. Polazeći od toga, Bosna i Hercegovina je konzekvenca geneze i postojanja historijsko geopolitičkog subjektiviteta, a Bošnjaci geneze i postojanja nacionalnog individualiteta.

Čaušević polazi od aksiomskog stajališta, $u$ to vrijeme prisutne južnoslavenske aksiologije, i konvencionalne predstave da su Srbi, Hrvati i Bošnjaci u Bosni i Hercegovini jedan te isti narod sa različitim imenima koja su dobili u određenim povijesnim trenucima. 
U njegovim radovima često se govori o «muslimanskom dijelu našeg naroda». ${ }^{6}$ Ovakav pristup inicira vrlo značajno pitanje: da li je bošnjaštvo integralna svijest bosanskog naroda diferenciranog, u vjerskom pogledu, na muslimane, katolike i pravoslavne?

Prije svega, on ne ostavlja nikakve nedoumice oko percepcije bošnjaštva kao integralne i neodvojive samosvijesti bosanskog naroda, koji - pored svih vidljivih povijesno prisutnih veza, jezika, kulture, zajedničke povijesti, svijesti o pripadnosti bosanskome tlu i južnoslavenskome porijeklu i drugih komponenta - čine bosanski identitet, ali i sa vidnim elementima religijske različitosti. Po njemu, identitet se formira kroz povijest i nije dostatnost koja je zaokružena, već je to proces (dugotrajni) koji traje i danas i koji će trajati u budućnosti. On pledira «bosanstvo» i smatra da je «najispravnije to da ni katolici svoje hrvatstvo, a ni pravoslavni svoje srpstvo ne spajaju sa svojim vjerskim osjećajima» ${ }^{7}$, mada je duboko svjestan jakog religijskog, po mnogima presudnog, utjecaja u procesu formiranja etniteta u Bosni i Hercegovini, a koji za svoju konzekvencu ima nacionalni trijalitet.

Situiranje misli Mehmeda Džemaludina Čauševića u ondašnji povijesni kontekst, ali i na vertikalu povijesti socijalne, političke, kulturne i vjerske misli u Bosni i Hercegovini, pokazuje da je on bio jedna od najznačajniji ličnosti tog perioda, a po mnogima i u ukupnoj bošnjačkoj povijesti, praveći snažne iskorake koji su od presudnog značaja za muslimansku egzistenciju toga vremena. U percipiranju bošnjačke nacije, bošnjački narodni identitet ne promatra samo kroz prizmu tadašnje aktualnosti tog pitanja, već u njegovom historijskom utemeljenju. Isto tako, insistira na historijsko-kulturnim dimenzijama bošnjaštva, što se uklapa u evropska iskustva u tretiranju nacije.

U konstitutivne elemente bošnjaštva, u njegovoj percepciji tog fenomena, ulaze ključni elementi koji će kasnije u evropskoj teorijskoj praksi biti poznati kao kulturološke definicije nacionalnog identiteta. U ovom kontekstu, Čaušević bošnjački identitet prepoznaje u povijesnim i kulturološko-duhovnim komponentama: narodna zajednička osjećajnost, tradicija, običaji, zajednička povijesna

\footnotetext{
${ }^{6}$ Džemaludin Čaušević, Okružnica", objav. u listu "Novi Behar" od 1. decembar 1928, str 161.

${ }^{7}$ Mehmed Džemaludin Čaušević, «Nacija $i$ vjera», Novi Behar, br. 1-3, godište IX, 1935. godine
} 
sudbina, moral, jezičko zajedništvo, književna i intelektualna produkcija i sl.

U tom kontekstu nameće se zaključak da je Čaušević jedan od onih bošnjačkih intelektualaca koji je, uz Mehmed-bega Kapetanovića Ljubušaka i Safvet-bega Bašagića, nacionalnu identifikaciju razumijevao u njenom kulturološkom određenju. Stoga je u svakoj ozbiljnijoj rekonstrukciji povijesti kulturoloških elemenata o naciji na prostorima Bosne i Hercegovine potrebno uzeti u obzir Čauševićev doprinos na tom planu.

Ulogu Džemaludina Čauševića na društvenom planu ne možemo objektivno predstaviti bez osnovnog prikaza društvenopolitičkih prilika koje su vladale u Bosni i Hercegovini, socijalnoklasne strukture i stanja svijesti kod Bošnjaka nakon susreta orijentalno-islamskog i zapadno-kršćanskog kulturno-civilizacijskog obrasca življenja. Bošnjaci su posredstvom religije ušli u jedinstven islamski kulturni krug i bili su integrirani u specifično osmansko društvo, u koje su ušli svi muslimani širom Carevine. Oni su u sklopu Osmanske carevine bili potpuno klasno strukturirano društvo, obuhvaćajući u sebi sve srednjovjekovne staleže: spahije, ulemu (svećenstvo), trgovce, zanatlije, slobodne seljake (raju). Klasne suprotnosti unutar muslimanskog društva u Bosni često su dovodile do otvorenog suprotstavljanja vladajućem sloju u Bosni a ponekad i centralnoj vlasti u Carigradu u vidu pismenih predstavki ili buna kao izražajnijeg vida nezadovoljstva. Bošnjaci su bili povezani, kako navodi Mustafa Imamović u knjizi «Historija Bošnjaka», sa dalekim centrima političkog, vjerskog i kulturnog života islamskog svijeta na ekonomskom, političkom, kulturnom i psihološkom planu. Sve te veze su prekinute austrougarskom okupacijom Bosne, a što za posljedicu ima decenijsko nesnalaženje u novim društveno-političkim prilikama. Prepušteni sami sebi i politički nedovoljno organizirani prinuđeni su prihvatiti novu civilizaciju. Alternativa tome bila je još pogubnija nestanak.

$\mathrm{U}$ toku prve dvije decenije austrougarske vladavine $\mathrm{u}$ bošnjačkom korpusu nisu vidljivi gotovo nikakvi značajniji socijalnopolitički pomaci. Društveni procesi koji su tekli, išli su u smjeru koji nije predviđao ravnopravno mjesto i ulogu Bošnjaka u novonastalim državnim formama. Rad Džemaludina Čauševića posmatramo u dvama pravcima: prvi, da se društveno-političkom borbom u novonastaloj multietničkoj i multikonfesionalnoj državnoj formi 
ostvari ravnopravan politički utjecaj Bošnjaka, što je bilo izrazito teško. Čaušević je ovom problemu pristupao aktivistički, često dovodeći u pitanje svoj biološki integritet. Drugi, borba protiv vjerskih stereotipa koji su duboko ukorijenjeni u tradiciji i koji su isključivali ideju progresa. I jedan i drugi vid borbe ne može se promatrati izolirano, već u interaktivnom odnosu. Ustvari, borba na društveno-političkoj sceni duboko je ovisila o uspješnosti borbe protiv vjerskih stereotipa i vlastitog konzervativizma. Uvidom $u$ Čauševićeve radove nameće se jedna generalna konstatacija koja ukazuje da je ključ bošnjačko-muslimanskog društvenog, političkog, ekonomskog, vjerskog i kulturnog napretka u njihovu odgojnoobrazovnom sistemu i odnosu prema njemu.

U sklopu ovih teorijsko-znanstvenih motiva svakako treba $\mathrm{u}$ fokusu interesiranja imati i motive bošnjačkog sukoba mišljenja, sukoba «starog» i «novog», odnosno konzervativnog i naprednog. Posljedica sukoba «starog» i «novog» unutar bošnjačkog naroda bila su pitanja odnosa spram školovanja ženske djece, nošenja šešira, pitanje feredže, odnosa prema bankovnim kamatama, latiničnom pismu i mnoga druga pitanja na koja Čaušević daje odgovore u duhu vremena koje dolazi, a koji se ne protive islamskom etičkom učenju što je u potpunom suglasju sa stavom hazreti Alije (četvrtog halife), koji kaže: «Odgajajte svoju djecu za vrijeme u kojem će živjeti, a ne za vrijeme u kojem živite..» 8

U tretiranju političke dimenzije Čauševićevog rada polazimo od činjenice da je smjena civilizacijskih svjetova u velikom dijelu Balkana, ${ }^{9}$ koja počinje 1878. godine dolaskom austrougarske imperije, uzrokovala pojavu krupnih društveno-političkih, ekonomskih, vjerskih i kulturnih promjena u Bosni i Hercegovini. Političke turbulencije na Balkanu početkom XX stoljeća zahvatile su i naše područje te su stvorile ambijentalne uvjete za afirmaciju ranijih težnji Srbije, i Hrvatske, potpomognuti Srbima i Hrvatima iz BiH, za teritorijalnim proširenjem i nacionalnom hegemonijom. Položaj Bošnjaka u sferama društveno-političkog, ekonomskog, kulturnog pa i religijskog života nije na istoj razini kao kod ostalih nacionalnih i religijskih skupina.

8 Citirano prema: Enes Karić, Mujo Demirović, Reis Džemaludin Čaušević prosvjetitelj i reformator, NIP Ljiljan, Sarajevo, 2002, str. 30.

${ }^{9}$ Indikativno djelo koje obrađuje bosansku zbilju je Zeleno busenje autora Edhema Mulabdića. 
Često političko osporavanje postojanja historijskog geopolitičkog subjektiviteta Bosne i Hercegovine i nacionalnog individualiteta, provođenje politike iseljavanja Bošnjaka, $\mathrm{s}$ jedne, te asimilacije, $\mathrm{s}$ druge strane, opredijelila je Čauševića u borbi za jednakopravnost svih nacionalnih i religijskih skupina u Bosni i Hercegovini. U tim promjenama Bošnjaci su se vrlo teško snalazili tako da je Džemaludin Čaušević, po mnogima, istinski bio jedina «institucija» koja je mogla izvući Bošnjake iz tog političkog nesuglasja.

Razumijevajući politiku i političku aktivnost u kontekstu definicije koju su dali Rod Hague, Martin Harrop i Shaun Breslin ${ }^{10}$ a u kojoj ovi teoretičari politike prave distinkciju između politike i političke aktivnosti u smislu da se svaki pojedinac može baviti određenim političkim pitanjima koja su od interesa šireg kruga građana, ili čak naroda, i tako neposredno utjecati na državnu politiku, a da za takvu aktivnost nije uvjet pripadnost nekoj političkoj stranci za Mehmeda Džemaludina Čauševića možemo reći da je dao jedan od najsnažnijih političkih doprinosa u pokušaju ostvarivanja bošnjačkomuslimanskih interesa i njihovih političkih prava. Pri vrednovanju njegovog političkog angažmana ne smijemo zaboraviti da je taj angažman van bilo koje organizirane političke stranke, kao i da su postojala razdoblja kada stranački politički život Bošnjaka uopće nije egzistirao i da je u takvim razdobljima institucija reisul-uleme bila jedina «zaštitnica» njihovih interesa.

S obzirom da su njegovo uključivanje u oblast politike diktirali događaji u tom periodu, u našem razmatranju političke dimenzije Čauševićevog djelovanja koristit ćemo kronološki slijed društvenopolitičkih događanja koja su zahtijevala njegovu političku reakciju. Nepunu godinu nakon njegova ustoličenja na funkciju reisul-uleme desio se poznati Sarajevski atentat (28.6.1914.g.), u kojem je Gavrilo Princip ubio austrijskog nadvojvodu Franza Ferdinanda. Posljedica ovog terorističkog čina je Prvi svjetski rat, a kao reakcija na atentat u Sarajevu organiziraju se brojni protesti protiv Srba. Brojne radnje i kuće srpskih trgovaca su opljačkane i demolirane. Džemaludin Čaušević, svjestan ozbiljnosti političkih prilika, svim muslimanima

\footnotetext{
${ }^{4}$ Rod Hague, Martin Harrop, Shaun Breslin, Komparativna vladavina i politika, Fakultet političkih znanosti Sveučilišta u Zagrebu, Biblioteka "Politička misao", Zagreb, 2001, str. 4.
} 
$\mathrm{BiH}$ odašilja poruku (koja je bila i vjerskog i političkog karaktera) u kojoj stoji da muslimani ne smiju učestvovati u uznemiravanju i progonima Srba.

U pogledu ponašanja Bošnjaka muslimana u ratnim prilikama Čaušević nije ostao pasivan prema ovom pitanju te je svojim čestim uputama koje su stizale u svaki kraj i selo Bosne i Hercegovine vršio vjerski i politički utjecaj u smislu kako treba da se odnose u ovakvim prilikama. Posebno je apostrofirao human odnos prema zarobljenima $i$ nemoćnima (tri decenije prije nastanka Ženevske konvencije) kao i razvijanje solidarnosti prema siromašnima.

Nakon završetka Prvog svjetskog rata (1918) Čaušević je sve do formiranja JMO (februar 1919) silom prilika bio ne samo vjerski već i politički predstavnik Bošnjaka - muslimana. Period u kojem su njegove političke aktivnosti dobile na intenzitetu i bile od ključnog značaja je od 1918. kada je bio ugrožen lični, imovinski i nacionalni, a često i biološki integritet Bošnjaka od strane vladajuće politike. Možda je jedina ozbiljnija bošnjačka institucija koja je stala u odbranu najelementarnijih bošnjačkih prava autoritet reisul-uleme Mehmeda Džemaludina Č́auševića.

U sferi vjere Čaušević ostavlja dubok i neizbrisiv trag koji je prepoznatljiv i danas poslije osam decenija. Osnovni i najvažniji zadatak koji on nameće i sa punom odgovornošću preuzima je očuvanje egzistencije islama u Bosni i Hercegovini, u čemu je, svi smo mi svjedoci, uspio.

Važno je da apostrofiramo njegovu borbu (naročito u razdoblju od 1918. do 1930. godine) za jednakopravnost svih religijskih skupina koje su prisutne u Bosni i Hercegovini uz puno međusobno uvažavanje. Odlaskom Osmanlija iz Bosne islam je često bio na meti raznih nacionalističkih i religijskih aspiracija smatran osmanskim «recidivom» koji je valjalo odvojiti od Bošnjaka. Budući da je bošnjačka identifikacija duboko određena i omeđena islamom, takav čin bi u realnosti djelovalo kao trganje dijela tijela organizma. Međutim, pored ovog vanjskog osporavanja islama, način na koji su tadašnji Bošnjaci muslimani čuvali islam više je odgovarao onima koji su se htjeli osloboditi tog «osmanskog ostatka» nego njima samima. Islam se nije mogao sačuvati vlastitom zatvorenošću prema kulturnim vrijednostima Zapada, kako su to činili konzervativni branioci islama, već, nasuprot tome, potpunom otvorenošću prema svemu naprednome bez obzira iz kojeg kulturno-civilizacijskog kruga 
to dolazilo. Protiv ovakvog redukcionističkog poimanja islama Džemaludin Čaušević se energično bori i pokušava afirmirati «pravu prirodu» islama, njegovu univerzalnost, nadvremensku i nadprostornu osobenost. Islam i Kur'an kao njegovo izvorište posjeduju stvaralački potencijal koji Čaušević svakodnevno ističe, ali taj potencijal mogu afirmirati jedino obrazovani muslimani. To znači da je ključ opstanka islama na prostorima $\mathrm{BiH}$ odgojno-obrazovni sistem na kojem je Čaušević neumorno insistirao. Isto tako, Džemaludin Čaušević je prvi put uveo držanje hutbe petkom na maternjem bosanskom jeziku. Ovaj vjerski (tada revolucionaran) poduhvat pravda time da muslimani moraju razumjeti islam (spoznajno ga prihvatiti), a to ne mogu ako im njegova ulema drži vazove (predavanja) na turskom ili arapskom jeziku koje većina stanovništva ne razumije.

No, ono po čemu će Čaušević biti često spominjan je njegov prijevod Kur'ana (1937) na bosanski jezik uz što je ponudio i tumačenje Kur'ana. Njegov doprinos u razvoju kur'anskih studija na prostorima Bosne i Hercegovine je neposredan i svako ozbiljnije razmatranje ove oblasti zahtijeva spominjanje njegovog rada na ovom polju.

$\mathrm{Na}$ planu kulture, posebno na polju kulturnog i društvenog preporoda Bošnjaka, Čaušević je ostavio neizbrisiv trag. On je smatrao svojom misijom da Bosnu i Hercegovinu, sa svim njenim orijentalno-islamskim vrijednostima, otvori ka Zapadu i njegovim vrijednostima; da Bošnjaci ne bojkotiraju naučni i tehnološki napredak zapadne civilizacije koji ima humani karakter i da za takvu otvorenost nije uvjet odricanje od vlastitih tradicionalnih vrijednosti.

Nesporan je njegov doprinos u stvaranju balansa između bošnjačke tradicije i progresa na način da kultura bude posredujući činilac tako što će selektirati iz njihove tradicije ono što je vrijedno i stavljati u «pogon» progresa. Ovakvim njegovim pristupom kultura ne ostaje samo na svjedočanstvu vremena (poput historije) nego reafirmira tradiciju i projicira progres tako da se tradicija ne bi reducirala na njeno ritualno ispoljavanje, a progres na «ekonomski materijalizam» koji je oslobođen duhovnosti. Na taj način Bošnjaci potvrđuju da su evropski narod i da svoj ukupni razvoj, kao i drugi narodi koji ovdje žive, povezuju sa kulturno-civilizacijskim tokovima pri čemu ni religija ni nacionalnost nisu prepreke tome, naprotiv one predstavljaju prednost. 
Isto tako, njegov doprinos razvoju bošnjačke publicistike, polemičke rasprave putem novina, časopisa, brošura i knjiga za posljedicu ima stvaranje polemičko-kritičkog mentaliteta kod Bošnjaka.

I na kraju, sa sigurnošću možemo ustvrditi da je Džemaludin Čaušević u odbrani interesa Bošnjaka muslimana i institucija islamske zajednice istupao dostojanstveno i državnički odlučno i sa osjećanjem misije u jednom teškom i bremenitom vremenu, iako je bio izložen brojnim iskušenjima $\mathrm{i}$ izazovima. Možda na pitanje ko je bio reis Mehmed Džemaludin Čaušević najslikovitije odgovara veliki bosanski književnik i njegov suvremenik Edhem Mulabdić, koji posthumno govori o ovom bosanskom velikanu:

"Ne laskati neukom narodu, govoriti mu i preporučivati $i$ ono, njemu tuđe, od čega su ga drugi odvraćali, a ipak uz to sve $i$ popularan postati, to je rijedak uspjeh, rijetko svojstvo $i$ rijetka vrlina, a u tom leži vrlina Mehmeda Džemaludina Čauševića." 
NEVZET VELADŽIĆ, M.A.

\section{SOCIO-POLITICAL AND CULTURAL DIMENSION OF WORK OF MEHMED DŽEMALUDIN ČAUŠEVIĆ}

\section{SUMMARY}

The attempt is to light up historical role of Džemaludin Čaušević, not only in religious, but, first of all, in socio-political and cultural importance. Especial attention has been paid to sociopolitical environment, because, as much as he was inspired by reformative ideas of Turkish youth, at the same time he was defined by the time and socio-political circumstances he lived in.

There almost has not been more turbulent period of time in entire history of Bosnia and Herzegovina than those last decades of the 19th and till a half of the 20th century. At that time history was recorded "every day» In that context, through the prism of historical events, the article shows the influence of Causevic upon the entire socio-political and cultural circumstances. It is certain that his influence was very strong. There are many confirming facts presented in the article. One of the most important facts is the way how he used to send messages to the society (population). Even though the media have not been developed well, number of information consumers was reduced. He used to use media very actively, but the best method of communication with the population was " mosque» - it was the shortest and the fastest way for his messages (a week) to get to the population of Bosnia and Herzegovina.

On the cultural plan, using the strength (power) of his own authority, he did his best to eliminate stereotype from Bosniac Muslims about western culture and everything what is associated to it, even certain number of "ulama" was burdened by those stereotypes, what made their work more difficult. The facts presented in this article confirm that Causevic belongs to a group of outstanding persons of the newest (modern) history of Bosnia and Herzegovina. 
الأستاذ نوزت ويلاجينش

البعد السياسي و الاجتماعي و الثقافي في عمل محمد جمال الدين تثاووشيويتش

الملخص

هذا البحث يحاول تسليط الضوء على الدور التاريخي الذي لعبه جمال الدين

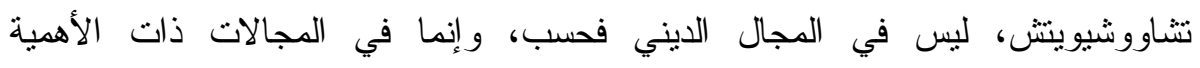

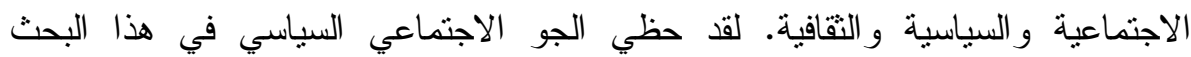

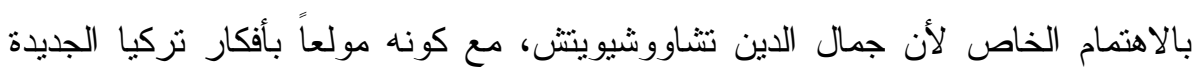

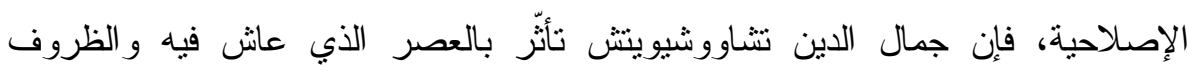

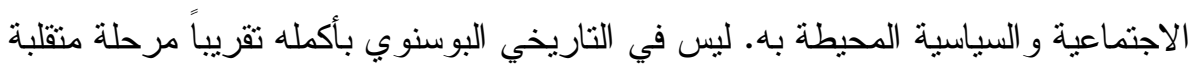

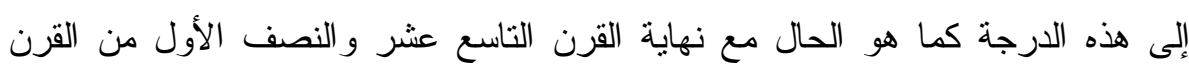

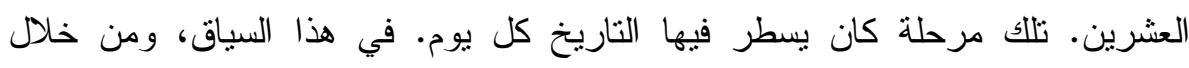

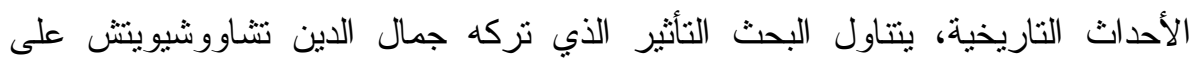
مجمل الأوضاع الاجتماعية و السياسية و النقافية.

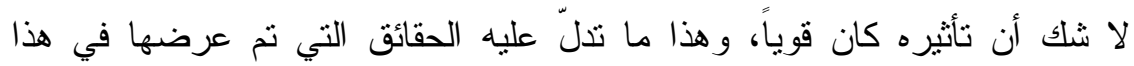

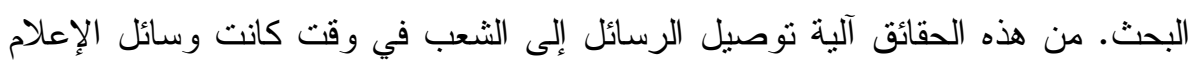

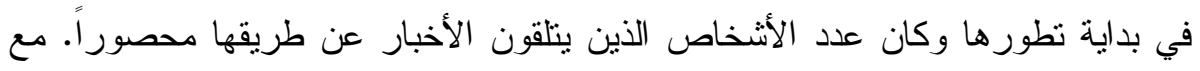

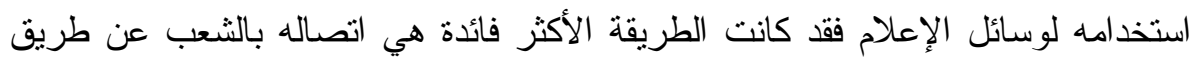

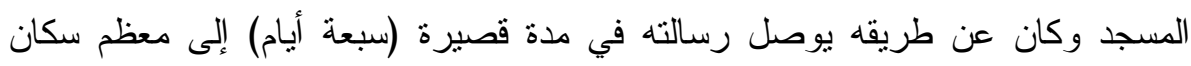
البوسنة و الهرسك.

في المجال الثقافي كانت قوة شخصيته تلعب دورها في إزالة الانطباع العام لدى الدى

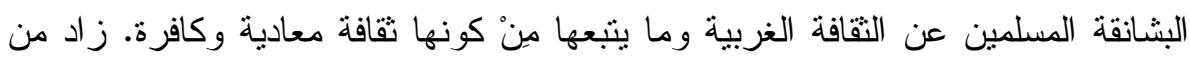
العو ائق في هذا المجال أن عدداً من علماء الدين كان يحمل ذلك الك الانطباع.

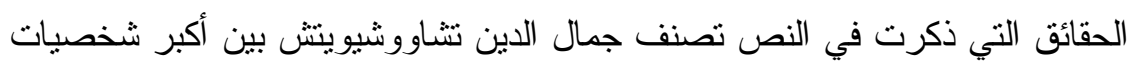
في تاريخ البوسنة و الهرسك الجديد. 